Оксана МИКИТЕНКО*

Інститут мистецтвознавства, фольклористики та етнології ім. М.Т. Рильського НАН України Київ
Оригинални научни рад

Примљен: 8. 11. 2020.

Прихваћен: 25. 2. 2021.

\title{
ТЕОРИЈСКО-МЕТОДОЛОШКА ПАРАДИГМА САВРЕМЕНЕ СЛАВИСТИЧКЕ ФОЛКЛОРИСТИКЕ: ИСКУСТВО МЕЪУНАРОДНОГ СЛАВИСТИЧКОГ ЦЕНТРА
}

\begin{abstract}
Данашња фолклористика истакла је као приоритет перспективу носиоца фолклора, усредсредивши пажњу на ментално здравље народа и комуникативне функције текста. Искуство Међународног славистичког центра је у синтези развојног континуитета класичне фолклористике као теорије усмене књижевности, уз методолошко обогаћивање прилазима савремене лингвистичке и културне антропологије. Научна школа допринела је истраживању у оквиру МСЦ-а различитих питања славистике и фолклористике историјско-књижевних, текстолошких, регионалних, међуетничких, урбане културе и сл. Као битно методолошко начело и полазна тачка анализе остају Вукова историја и теорија усменог стварања - научно признати маркери „историјског континуитета и интегритета српског народа" (Милошевић-Ђорђевић).

Кључне речи: савремена славистичка фолклористика, теорија и методологија, Међународни славистички центар.
\end{abstract}

Између појава које данас одређују актуелност словенске фолклористике и постављају питања граница њеног предмета и метода истраживања посебно се издвајају задаци заштите нематеријалне културне баштине и интердисциплинарни карактер савремене европске хуманистике са улогом екологије културе. Узрок теоријско-методолошког ширења научне парадигме фолклористике (као и увођења метода теорије комуникације и структурне антропологије у домен народне књижевности) повезан је са дефиницијом текста као поруке и традиције као интерпретације културне баштине. Теоријско-методолошка парадигма словенске фолклористике огледа се у оквиру њених „карактеристичних особина", које је навео Љ. Раденковић на XIV Конгресу слависта (2008). Између основних истакао је померање интереса са спољашње

\footnotetext{
*oksana_mykytenko@hotmail.com
} 
стране фолклорних појава на њихов унутарњи аспект, усавршавање научног апарата истраживања, примењивање метода лингвогеографије, структурне лингвистике и поетике, теорије комуникације и структурне антропологије.

Нове идеје на прелому XX и XXI в. довеле су, - нагласио је Љ. Раденковић, - до процвата семиотике и етнолингвистике. На нов начин схваћене су везе фолклора са другим знаковним системима - обредом, обредним радњама и предметима, а такође временско-просторним концептима културе. У семиотичким истраживањима увек се у центру пажње налази текст без обзира на то, која га знаковна средства изражавају (Раденковић 2008a).

Садашња фолклористика чврсто је повезана са општим антропоцентричним правцем савременог научног знања, са посебно запаженим напуштањем системне сфере и оријентацијом на човека који постаје центар свих система. Проблем ,језик и мишљење”, оцењен у лингвистици као прелаз од анализе објекта (анализе језичке јединице или говорне појаве) према субјектној анализи, односно људском фактору у језику, довео је до формирања заједничких појмова и међудисциплинарних метода, карактеристичних за низ „млађих дисциплина" - антропоцентричне и когнитивне лингвистике, семиотике, дискурсне анализе, лингвокултурологије, етнопсихолингвистике, лингвоконцептологије и сл. (Ивашћенко 2006: 3). Паралелно са дефиницијом фолклора као „усмене (народне) књижевности” терминолошко-појмовна ширина рачуна на синкретичност фолклорног текста и његову реализацију - пренос поруке, за шта се користе различити кодови - вербални, акциони, предметни и др, тражећи одговор на питање, на који начин човек/група људи моделује свет око себе (Раденковић 2008: 9).

Фолклорни текст одређује се као системска и сложено организована самостална јединица у делокругу културне традиције. Управо у границама текста, целовитог у садржајном, композиционом и функционалном односу према фрагменту традицијске културе, на основу комплекса језичких средстава реализује се један или други облик уметничке форме (Мехнецов 2005: 362). Уметнички критеријум за фолклор, према Н. Толстоју, могућ је само у одређеном смислу, међутим његова апсолутизација „оставља у сенци или потпуно искључује” дијалектолошки, ареални и структурно-типолошки прилаз фолклору и народној култури у целини, која представља „одређени систем погледа на свет и народних представа, систем жанрова и изражајних средстава, систем ритуалних функција и текстова, одређеног и потврђеног традицијом садржаја" (Толстој 1989: 13).

Следећи транспарентност научног знања и универзални „интегративни модел” (термин А. Каргина) комплексне анализе фолклора, искрсло је питање о границама предмета словенске фолклористике и метода истраживања. Узрок, према многима (упор. Брицина 2009), лежи у различитим тумачењима појма „фолклор”, о чему се говорило на Међународном научном симпозијуму из фолклористике (2006) и на заседању Комисије за фолклор при Међународном комитету слависта (Раденковић 2008). Појам „граница у фолклору” био је кључна тема научног скупа „Савремена српска фолклористика IV", одржаног у Источном Сарајеву/Палама 2016, а такође разматрао 
се у оквиру нашег тематског блока на XVI Међународном конгресу слависта у Београду 2018 г. (Микитенко 2018).

Проблем „границе у фолклору” (присутан у истраживању жанрова и њихових веза, узајамном утицају усмене и уметничке традиције, традицијске и урбане културе, фолклора и фолклоризма итд), односно који обухвата разноврсне задатке теоријске анализе и примењене науке, заједно са заштитом нематеријалне културне баштине и интердисциплинарним студијама из домена најширег „фолклорног поља” (термин А. Наљепина), следи актуелност словенске фолклористике данас и њен значај у контексту савремене хуманитаристике. Подесан за научни дискурс у промењеним социокултурним условима појам „фолклорног поља” подразумева одређени етнокултурни простор који је истовремено повезан са конкретним фолклорним творбама, регионалним или локалним традицијама и народном културом у целини, а на тај начин се јавља као битан фактор самоидентификације народа и његове менталности. Доминантна у „фолклорном пољу” „фолклорна самосвест” одређује његов непрекидни развој, континуитет традиције и очување културног генофонда једног национа, а такође пружа креативне могућности у новим условима проширених граница етнокултурног простора (Наљепин 2018 : 142). Непосредно везани са масовном културом савремени облици постојања фолклорне традиције, протичу „углавном изван естетских критерија, са промењеном функцијом и наменом и у другачијем виду" (Милошевић-Ђорђевић 2000: 27).

Данашња фолклористика која истражује ,„разноврсне и полифункционалне” (Каргин 2008) појаве фолклора у новим „границама” дискурса, активно је ушла у нову методолошку парадигму и окренула се проучавању тема, раније маргиналним за фолклористику (комуникативне особине фолклорног текста или прагматични утицај текста на адресата). Захтеви за методолошку модернизацију фолклористике углавном се односе на промену интерпретације фолклорног текста, заправо - померање са текста-дела на текст-понашање, текст-процес, проширивање фолклорног текста до свеобухватности комуникативног акта и текста културе (Микитенко 2007: 124).

Прекор, који је П. Коваљски упутио „парадигми фолклористике”, тиче се доминације у данашњој науци, исто као и у традицијској, „перспективе истраживача". Без претензије да буде нов, овај поглед пољског научника продужио је од средине XX века актуелне захтеве представника различитих школа и праваца о неопходности проучавања традицијске културе „изнутра”, који су у научну употребу уводили дефиниције „унутрашњих” метода анализе: иманентне, когнитивне, феноменолошке и др. Напоредо са концептуалном анализом, феноменолошки приступ, треба да се разуме као „интерпретација симболизма феноменолошке стварности културе, односно њеног симболичног језика”. То обухвата „слој свих знаковних средстава, функције које могу да врше било који њени [традицијске културе - O. M.] елементи, компоненте, а такође њихови комплекси/комбинације: материјални, вербални, звучни, уметнички, емотивни и кинетички - гест, покрет, пантомима". Такви приступи, према Т. Бернштам, могу да укину дихотомију култура/стварност и 
култура/феномен (Бернштам 2005: 256). Везан за постулат „субјективног” разумевања културе, феноменолошки прилаз води нас у ону област, где се фолклористика граничи са културном антропологијом и когнитивном лингвистиком, односно у круг проблема етнонауке (Бартмињски 2005: 112), која фолклор проучава у контексту „човекознања” (Бернштам 2005: 248).

„Нова” - антрополошка фолклористика, која следи постулате performance-centered theory и оријентише се на савремену урбану културу, свакодневну културну праксу, симболичну комуникацију и облике понашања у малим групама, има своје запажене резултате, као и методе анализе. На тај начин ,антрополошка димензија” у књижевнотеоријским проучавањима омогућује да се пронађе и истакне веза између текста, као финалног производа фолклорно-поетске комуникације, и друштвеног контекста. Д. Антонијевић, говорећи о антрополошком и структуралном аспекту проучавања код Н. Милошевић-Ђорђевић, истиче да код овог „доајена савремене српске фолклористике” антрополошке методе имају шири научни значај, а њена су проучавања легенди, етнолошких и културно-историјских предања показала колико је важно познавање социокултурног контекста у тумачењу усмених наратива, за разумевање улоге у преношењу традицијског знања, у друштвено-етичком нормирању и одржавању колективног сећања (Антонијевић 2011: 44).

Међутим, формални антрополошки приступ често пренебрегава такве неопходне атрибуте фолклорног текста, као што су етничност, аутентичност, уметничка вредност и сл, које се померају у домен „рецептивне естетике”. У исто време апсолутизација методе антрополошке школе, карактеристична за „нову” фолклористику, када се „фолклорност” тражи не у тексту, него искључиво у његовој прагматици, односно у „социолошко-идеолошком контексту трансмисије” (Панченко 2005: 88), маргинализује задатке фолклористике, и заједно са напуштањем „широке перспективе народа” своди се на „врло уску” - перспективу „човека као појединца у савременом друштву” (Раденковић 2008: 10).

Као једно од најважнијих, поставља се питање о „традицији” - категорији која се тумачи као имагинарна и субјективна интерпретација културне баштине, са реализацијом у хипертексту, односно као дијалогично формирани облик репрезентације културе (Ђорђевић 2012: 94). Такви појмови, као што су „етничка традиција”, „идентичност”, у епоси глобализације, а нарочито под условима данашње трансграничне мобилности, добијају, сматра П. Христов, нови смисао. У науци се тражи одговор које су то ознаке, које маркирају данашњу етничку културу, које симболе - реалне или конструиране користи аутентична традиција. Према Христову, етничка идентичност, која је иначе однос према сличном или различитом услед разграничења културних целина, представља процес који се одвија стално, и према томе је разлог за разумевање традиције као „интерпретације културне прошлости” (Христов 2013, 10-12). Међутим, таква је дефиниција „традиције”, делотворна и ефикасна, када је реч о културној делатности нових дијаспора и формирању одговарајуће политике према мигрантима, у ствари једнострана и није довољ- 
на за адекватни приказ једне од основних појмовних категорија. Приметимо да је Н. Толстој ставио знак једнакости између културе и традиције, када је навео метафору културе као „обрађивања, очувања националне њиве”, нагласивши да „све што је национална култура и све што има традицију, стару традицију, битно је. И оно што нам се чини да сада, моментално, није битно, то ће бити битно кроз, рецимо, 100 година. Култура је традиција” (Јевтић 1991: 176).

Не улазећи у могуће дискусије око потоњих противречности ставова појмовног апарата „нове” фолклористике, када се евентуално елиминише и сам појам фолклора, навешћемо мишљење Б. Путилова из његовог писма 1997. г. И. Земцовском у САД. Путилов сматра за потребним објаснити америчким студентима смисао његове „историјско-типолошке теорије фолклорног текста", коју је образложио у својим радовима, полазећи од става да је фолклор самостални и себи довољни културни феномен, који има своју „властиту стварност”. Том приликом Борис Николајевич је нагласио да се његова теорија разликује од теорија антрополошке и психолошке школе и приметио да је за њих „специфичност фолклорног стваралаштва остала иза седам печата”, јер су „одлучујуће факторе и федере” тражиле „ван фолклора”. Мада теорије „долазе и одлазе”, отпорност је историјско-типолошког правца, према Путилову, у томе, што ће још прибављати „нове и нове податке”, и оставити их рано (Земцовски 2005: 90). Путилов је написао те речи у септембру 1997, месец дана пред крај свог живота. Раније је, у свом реферату Косовский цикл и фольклорно-этнографические традиции, који је изнео у Београду на Међународном научном састанку слависта у Вукове дане 1989, говорио о потреби „унутрашње” анализе косовског циклуса, полазећи од разумевања унутрашњих законитости у процесу стварања епа, и том приликом нагласио јединство „закона циклизације” као важан чинилац типологије епског стваралаштва (Путилов 1991).

Несумњиво је да је управо славистика (у коју се убраја и фолклористика) имала и има широки обим радних теоријско-методолошких средстава и приступа, битних за решавање најважнијих теоретских питања - генетске основе, историјско-типолошких веза и културних контаката, порекла класичних жанрова словенског фолклора, ареалне поделе мотивско-сижејних облика и др. Према ауторитативном мишљењу А. Панченка, „традицијски фолклористички и етнолошки инструментариј (опис и анализа мотива и сижеа, истраживање структуре, функција, семантике и прагматике текста и ритуала, разматрање наративне праксе и стратегије, историјско-типолошка и историјско-географска анализа итд) омогућује да се проучи разноврсност форми и типова, присутних у култури обичног живота, без опасности да буде сведен на много строжи и једноличнији појмовни апарат социологије и лингвистике”. Управо међудисциплинарни простор фолклористике дозвољава „гипки и корисни спој филолошких и нефилолошких (историјских, социолошких, психолошких) метода истраживања културе" (Панченко 2005: 92). Антропоцентрички принципи савремене науке, ослањајући се на поуздане ставове теоријског знања, полазе од повезаности језика, фолклора и менталитета наро- 
да, узимајући у обзир комуникативне и функционалне могућности речи, које се огледају у националној слици света и приказане су у фолклорном тексту.

Данас општепризната идеја комплексне и међудисциплинарне анализе фолклора, која је једино способна „да пружи нов облик фолклористици и повећа њен значај као целовите и универзалне науке, која располаже адекватном базом за квалитетно проучавање фолклорних текстова и традиција" (Каргин 2008: 340), у славистици је заступљена већ одавно. Можемо споменути реферат Комплексное (междисциплинарное) изучение фольклора на XII Међународном конгресу слависта у Кракову (1998), који је поднео дугогодишњи председник Комисије за фолклор Виктор Гусев. Нагласивши да је комплексно и међудисциплинарно проучавање фолклора код сваког словенског народа „вредно посебног и специјалног осврта”, Гусев је изнео углавном историју проучавања у Русији, а навео „узорак” универзалне делатности у XIX в. - радове у више томова Вука Караџића и Оскара Кољберга. Заједно са „принципијелном променом места” у систему културе, када фолклор постаје „основни и себи довољни” предмет фолклористике, почиње његово комплексно изучавање као „сложене полиелементне структуре”. Фолклористика се обраћа искуству и методологији сродних наука, а међудисциплинарна анализа има за циљ да објасни специфичност предмета истраживања фолклора (Гусев 1998: 357).

Као дугогодишњи учесник Међународних научних састанака слависта у Вукове дане, које организује Међународни славистички центар, са пуно разлога могу да укажем на континуитет традиције комплексне анализе усменог и књижевног текста као основну компоненту научног дискурса. Заснована на синтетичном делу Вука Караџића, које је означило „дефинитиван прелаз ка народном језику као основици књижевног језика", а постало „темељ” и „преломна књига српске националне културе” (Сувајџић 2018: 477), дијахрона анализа захватила је најшири спектар интердисциплинарних истраживања. Ставови Вука Караџића, који не само што је „формирао историју и теорију усменог стварања, али и своја тумачења ставио у функцију шире идеје о историјском континуитету и интегритету, особеностима и карактерологији српског народа" (Милошевић-Ђорђевић 2018: 12), одређују ширину методолошке парадигме и остају у средишту пажње славистике. Други је, од пресудног значаја, „темељ” идентитета културне традиције (а такође и научног дискурса) - прецедентни текст косовске епике, која „живи и буја на свим нашим подручјима, представља непресушну инспирацију писаној књижевности, основни је извор очувања националног бића [...] и интегративни елемент свеукупног словенског југа” (Милошевић-Ђорђевић 2011: 218). Значај Косова као културног кода условљава комплексно проучавање епске традиције, нарочито из аспекта антропоцентричне анализе, са посебном пажњом према певачу као носиоцу колективног памћења у контексту развијања културног идентитета једне заједнице (Сувајџић 2010: 89). Афирмација нових генерација слависта доприноси ширењу интердисциплинарних књижевних и културолошких истраживања актуелних проблема савременог научног знања. 
Разноврсна делатност Међународног славистичког центра, посебно вишедеценијско одржавање научних састанака слависта (жива стручна комуникација која се одвија посредством поднетих реферата и истакнутих проблема, дискусије и размене научних погледа, разноврсни теоријски прилази, обим фолклорних записа, избор теоријске грађе итд) допринела је развоју различитих питања славистике и фолклористике - историјско-књижевних, текстолошких, регионалних, међуетничких веза, „треће” и урбане културе, постфолклора и сл. За мене све то представља једну велику и значајну школу, а уједно и важан критеријум за обликовање властитих стручних погледа, једно огромно искуство, које је пружило прави увид у српску културу, посебно усмено-књижевну традицију, и омогућило проницање и разумевање основних покретача њене трајности, изражајности и богатства.

Не тако давно Г. Невекловски је у разговору са М. Јевтићем, а на питање о улози славистичких скупова, приметио да је „научни скуп слависта у Вукове дане кориснији од великог скупа" [Међународног конгреса слависта - O. M.] због тога што „најплоднији састанци су мањи састанци, на којима се говори о једној одређеној теми. На мањим научним састанцима су сви учесници на окупу, па се може разговарати са сваким, и то у било које доба. То је врло важно. Поред предавања, веома много значе и ти разговори о разним темама. У њима сазнајемо шта се збива у нашој науци, на којим пројектима се ради, које се књиге објављују, ко шта ради и тако даље” (Јевтић 1991: 476). Потпуно делим мишљење истакнутог аустријског слависте.

На овогодишњем јубиларном скупу Б. Сувајџић је у свом реферату дао исцрпни оглед тематике из фолклористике током педесет година. Важно да је сваки проблем, који је био предмет шире анализе, - било да је то прожимање жанрова, специфичност приказивања стварности у уметничком тексту, упоредно проучавање текста, контекста и интертекстуалности, или да су у питању узајамни културни утицаји у контексту европских и светских веза, ентитет традиције и савремена култура, међуоднос националног и универзалног, глобализација и идентитет итд, - заправо део фундаменталних поставки данашњег хуманистичког знања, а уједно и дубинска комплексна анализа словенске, посебно српске културе. Истовремено, начела Вукове историје и теорије усмености стварања остају битно методолошко начело и полазна тачка савремене научне анализе, а Вукова дела - стална инспирација за најсмелије модерне научне подухвате.

У светлу постављене теме од битног значаја је, чини се, једини пример непрекидне вишедеценијске праксе одржавања научних скупова, упоредо са традицијом редовног издавања зборника, што чини програмски-тематскиметодолошки-аксиолошки континуитет националне научне школе славистике. У сажетом Предговору „Биобиблиографском речнику” (2005) 3. Бојовић је приметила да „по својој природи и резултатима Научни састанак слависта у Вукове дане заузима посебно место међу скуповима сличне врсте - повременим, јубиларним и специјализираним симпозијумима или научним колоквијумима у оквиру тзв. летњих школа" (Бојовић 2005: 5). Ово запажање о „летњим школама”, а које се сасвим оправдано односи и на одржавање саста- 
нака слависта, у ствари следи демократски хеленистички принцип научног школовања. Издати зборници, а такође, поводом тридесетогодишнице рада Међународног славистичког центра, публиковани „Библиографски речник”, са библиографијом учесника и пописом најважнијих дела аутора, међу којима су светски позната имена (многи, нажалост, више нису са нама), а поред њих су млади истраживачи, - приказују „суштину и богатство научног размишљања о најважнијим темама српског језика и књижевности" (Исто: 6). Значај речника и зборника реферата за савремену славистику, у том смислу и фолклористику, као и за континуитет научног дискурса, доиста је огроман.

Улога школе и научне традиције свуда је од пресудног значаја. Да наведем и један негативан пример из моје скорашње праксе. Позвана да напишем одзив на аутореферат једне докторске дисертације, нисам могла да прихватим тенденциозни покушај аутора да за анализу изабере „идеолошки одговарајућу" фолклорну грађу (радило се о периоду Првог и Другог светског рата) и да се дистанцира или потпуно негира научну истраживачку и издавачку праксу претходног периода (до 1991. г). Да образложи свој став, аутор је неосновано поделио континуитет фолклористичког проучавања на субјективно одабране периоде: „предсовјетски - светопогледни; совјетски - између фејклора и аутентике; постсовјетски - међудисциплинарни" (Кузменко 2020: 10) (курзив аутора - О. М.). Нажалост, слични погледи, када се заправо ради о вулгаризацији и идеолошкој ангажираности, а уз недовољну стручну упућеност без увида у искуство научне традиције, сада нису ретки, и не само у украјинској фолклористици.

Али и то није страшно. Учимо се током целог свог живота, и то је нормално. Знам колико је важно представљати у домаћој научној средини актуелне проблеме савремене славистике, говорећи о себи - славистичке фолклористике. Увек када се вратим са Научних састанака слависта, настојим да пренесем своје утиске и знање колегама, и на тај начин стечено искуство проширим као у концентричним круговима. Хтела бих да споменем и наш заједнички пројекат под насловом „Славистичка фолклористика у Украјини и Србији: савремени методолошки принципи и етнонационалне димензије у контексту европске хуманитаристике”, у оквиру којег је био објављен посебан број часописа Народна творчість та етнологія (2/2012) Института за етнологију и фолклористику НАН Украјине (уредници издања Љ. Раденковић, Б. Сувајџић, Д. Ајдачић). Презентацијом актуелних радова од двадесет аутора, часопис је пружио увид у разноврсност проблема српске фолклористике, а такође је представио континуитет истраживачких школа у различитим научним центрима (Београда и Новог Сада, Косовске Митровице и Српског Сарајева). И у томе такође почива искуство Међународног славистичког центра.

Свакако, најважнији у сваком искуству је лични, непосредни доживљај. Без пријатељских сусрета, комуникације, разговора и консултација, дискусија и искреног дружења, тешко се да̂ замислити стечено искуство, захваљујући Научним састанцима слависта у Вукове дане. И зато свима, који се налазимо у једној великој „словенској породици”, желим много успешних 
стваралачких подухвата, надајући се нашим новим сусретима у Београду под окриљем Међународног славистичког центра.

\section{ЛИТЕРАТУРА}

Антонијевић 2011: Д. Антонијевић, Антрополошки и структурални аспект проучавања Наде Милошевић-Ђорђевић и применљивост њених методолошких истраживања, у: (ур.) М. Детелић, С. Самарџија, Жива реч, Зборник у част проф. Наде Милошевић-Ђорђевић, Београд, 43-56.

Бартмињски 2005: Е. Бартминьский, Фольклористика, этнонаука, этнолингвистика - ситуация в Польше, Первый Всероссийский конгресс фольклористов, т. I, Москва: Государственный республиканский центр русского фольклора, 106-117.

Бернштам 2005: Т. Бернштам, Русская народная культура: действительность и феномен, Первый Всероссийский конгресс фольклористов, т. I, Москва: Государственный республиканский центр русского фольклора, $244-257$.

Бојовић 2005: 3. Бојовић [Предговор], у: Биобиблиографски речник МСЦ 1971-2000, Београд: МСЦ, 5-7.

Брицина 2009: А. Брицына, Навстречу II Всероссийскому конгрессу фольклористов, Живая старина, 4 (69), 2-3.

Гусев 1998: В. Гусев, Комплексное (междисциплинарное) изучение фольклоpa, у: (ред.) С. Никольский, Славянские литературы, культура и фольклор славянских народов / ХІІ Международный съезд славистов (Краков, 1998). Доклады российской делегаџии, Москва: Наследие, 357-369.

Ђорђевић 2012: С. Джорджевич, Методологічні проблеми територіального дослідження фольклору: репертуар гуслярів, Народна творчість ma етнологія, 2, 94-100.

Земцовски 2005: И. Земцовский, Героический эпос жизни и творчества Бориса Николаевича Путилова, Санкт-Петербург: Европейский Дом.

Ивашћенко 2006: Л. Іващенко, Концептуальна репрезентація фрагментів знання в науково-мистецькій картині світу (на матеріалі украӥнської мистецтвознавчої термінології), Київ.

Јевтић 1991: М. Јевтић, Са светским славистима, Горњи Милановац: Дечје новине.

Каргин 2008: А. Каргин, Мультидисциплинарный подход к изучению фольклора, ХIVMеѓународен конгрес на слависти, Охрид, 10-16 септември 2005 / (ур.) Н. Радически, С. Веновска-Антевска, Зборник на резимеа, т. II, Скопје: Македонски славистички комитет, 340.

Кузменко 2020: О. Кузьменко, Драматичне буття людини в украӥнському фольклорі: Кониептуальні форми вираження (період Периої та Другої світових воєн), автореферат ... доктора філологічних наук, Київ. 
Мехнецов 2005: А. Мехнецов, О задачах комплексного исследования фольклора, Первый Всероссийский конгресс фольклористов, т. I, Москва: Государственный республиканский центр русского фольклора, 360-371.

Микитенко 2007: О. Микитенко, Модалитет као услов моделирања фолклорне стварности: покушај когнитивне карактеристике, Научни састанак слависта у Вукове дане, 36, 2, 123-132.

Микитенко 2018: О. Микитенко, Межі фольклору vs. моделі поля інтерпретацій фольклорного тексту, у: (ур.) Т. Ракић, А. Корда Петровић, Међународни конгрес слависта. Тезе и резимеи / Кюижевност, култура, фолклор, питања, Београд: Међународни комитет слависта: Савез славистичких друштава Србије, 2, 297-298.

Милошевић-Ђорђевић 2000: Н. Милошевић-Ђорђевић, Народна књижевност, у: (ур.) Н. Петковић, Кратак преглед српске књижевности, Београд: ЛИРИКА, 25-52.

Милошевић-Ђорђевић 2011: Н. Милошевић-Ђорђевић, Радост препознавањ $а$, Нови Сад: Матица српска.

Милошевић-Ђорђевић 2018: Н. Милошевић-Ђорђевић, Српска народна књижевност у светлости Вуковог Рјечника (1818), у: (ур.) Љ. Бајић, Српска славистика. Колективна монографија. Радови српске делегащије на XVI међународном конгресу слависта, т. II. Кюижевност, култура, фолклор, питања славистике, Београд, 7-14.

Наљепин 2018: А. Налепин, Всякая фольклорная всячина, прочие фольклорные пустяки ушедшего времени и современный литературный процесс, Традиционная культура, 19/4, 137-157.

Панченко 2005: А. Панченко, Фольклористика как наука, Первый Всероссийскийконгресс фольклористов, т. I, Москва: Государственный республиканский центр русского фольклора, 72-95.

Путилов 1991: Б. Путилов, Косовский цикл и фольклорно-этнографические традиции, Косовски бој у књижевном и културном наслеђу / Научни састанак слависта у Вукове дане, 19/1, 279-284.

Раденковић 2008: Љ. Раденковић, Поглед на словенску фолклористику, у: (ур.) Љ. Раденковић, Словенски фолклор и фолклористика на размеђи два миленијума, Зборник радова са међународног научног симпозијума, Београд: САНУ, Балканолошки институт, посебна издања 101, 7-11.

Раденковић 2008а: Љ. Раденковић, Славянский фольклор и фольклористика на рубеже XX-XXI веков - текст и контекст, XIV Меѓународен конгрес на слависти, Охрид, 10-16 септември 2005 / (ур.) Н. Радически, С. Веновска-Антевска, Зборник на резимеа, т. II, Скопје: Македонски славистички комитет, 341.

Сувајџић 2010: Б. Сувајџић, Певач и културни идентитет, Книжевност и култура / Научни састанак слависта у Вукове дане, 39/2, 89-101.

Сувајџић 2018: Б. Сувајџић, Српски рјечник (1818) у Вуковој Преписци, у: (ур.) Љ. Бајић, Српска славистика. Колективна монографија. Радови српске делегаиије на XVI међународном конгресу слависта, т. II. Кюижевност, култура, фолклор, питања славистике, Београд, 477-489. 
Толстој 1989: Н. Толстой, Некоторые соображения о реконструкции славянской духовной культуры, у: (ред.) Н. И. Толстой, Славянский и балканский фольклор. Реконструкция древней славянской культуры: источники и методы, Москва: Наука, 7-22.

Христов 2013: П. Христов, Традиция и идентичност в условията на европейска трансгранична мобилност, Българска етнология, 1, с. 7-14.

\author{
Оксана Микитенко
}

ТЕОРЕТИКО-МЕТОДОЛОГИЧЕСКАЯ ПАРАДИГМА СОВРЕМЕННОЙ

СЛАВИСТИЧЕСКОЙ ФОЛЬКЛОРИСТИКИ: ОПЫТ МЕЖДУНАРОДНОГО СЛАВИСТИЧЕСКОГО ЦЕНТРА

\begin{abstract}
Резюме
Сегодняшняя фольклористика, определив своим приоритетом перспективу носителя фольклора, основное внимание обратила на ментальность народа и коммуникативные функции текста. Опыт Международного славистического центра состоит в синтезе развития непрерывности классической фольклористики как теории „усной литературы”, при методологическом совершенствовании за счет подходов современной лингвистики и культурной антропологии. Научная школа поддерживала изучение в рамках МСЦ многих проблем славистики и фольклористики - историко-литературных, текстологических, региональных, межэтнических связей, урбанистической культуры и под. При этом среди наиболее важных методологических принципов и исходных позиций анализа остаются Вуковская история и теория устного творчества как научно признанные маркеры „исторического континуума и целостности сербского народа” (Милошевич-Джорджевич).
\end{abstract}

